\title{
NATURAL RESOURCES PROTECTION STRATEGIES IMPORTANT FOR AGRICULTURE IN THE INTERNATIONAL COMMUNITY AND REPUBLIC OF SERBIA
}

\author{
Slobodan Nešković, Verica Savić
}

*Corresponding author E-mail: slobneskovic@gmail.com

A R T I C L E I N F O
Review Article
Received: 26 March 2018
Accepted: 08 May 2018
doi:10.5937/ekoPolj1802813N
UDC [005.21+502.171]:631(4/9)(497.11)

Keywords:

strategy, natural resources, international community, environment, agriculture

JEL: Q15, M24

\begin{abstract}
A B S T R A C T
Agriculture as an economic activity depends heavily on living organisms and ecosystems for its vulnerability of nature and therefore the environment has become a common global problems of the modern world. International legislation in the field of environmental protection has not yet reached the level that would allow a peaceful life for all people and all living creatures on our planet. During this research various methods of scientific research were used in the breakdown of complex categories, methods of specialization and after synthesis elaboration, different conclusions were formed. On the basis of the aim of this paper, the methods are chosen which by their combination enable the quality realization of the research.
\end{abstract}

(C) 2018 EA. All rights reserved.

\section{Introduction}

The high threat to nature and the environment becomes part of the common problems of contemporary civilization. As a process of modern times, urbanization manifests itself through the increasing role of cities in human life, in terms of population concentration, urban and economic functions that become the paradigm of human life created by the social-spatial forms of habitation. Forms of environmental degradation constitute a complex process that contains the phenomena and events that occur from the behavior of a person or the use of technological systems. Namely, these forms are not only the result of urbanization and industrialization, but are primarily present in the disregard of ecological environmental laws, poor spatial and urban planning, including the susceptibility to a long array of risks (Mijatović, Cvijanović \& Stajkovac, 2011).

There is an impressive range of evidence demonstrating the agricultural impact on the enviroment, confirming a serious extent of damage to ecological infrastructure, including species extinctions, top soil loss, water scarcity, deforestation, air pollution, acid rain, green house effect, ozone hole, collapsing fisheries, bio-invasions and increasing infectious disease. The industrial agriculture system consumes fossil fuel, water, and topsoil at unsustainable rates. It contributes to numerous forms of environmental degradation, including air and water pollution, soil depletion, diminishing biodiversity, and fish die-offs (Altieri, 2004). 
Pollution and contamination are concepts that need to be distincted from one another, because pollution includes qualitative and quantitative changes in the physical, chemical and biological properties of primary life components (air, water, soil, food, etc.) and pollution, which is the current cross-section of the condition caused by the previous process and which has its duration. One of the functions of the state is the preservation and protection of nature, the activity of professional institutions, the obligations and freedom of civic action and behavior, aimed at preserving biodiversity, geo-heritage (geodiversity) and landscape with its aesthetic characteristics, natural and cultural contents. (Nešković, 2007).

\section{Materials and methods}

The research is supported by knowledge and results from scientific and professional literature, that is, the findings and scientific results of numerous professional authors who have studied the issues of this work in their books and articles. In this research, we specifically deal with agriculture as an economic activity that largely depends on the environmental protection and ecosystems due to its productivity and sustainability.

During this research, techniques of classifying different data through literature review, as well as the method of description and generalization, have been applied. Using the descriptive method, we present the results that were obtained by looking at the effects of the initiated process of protection of important national resources in our country. The comparative method was inevitable in the writing of this research paper and it will show similarities and differences between global standards in protection of national resources within agricultural systems and state of environmental protection in the Republic of Serbia.

\section{Results}

The main result of this research is the identification of the process of environmental protection and national resources protection strategy of the Republic of Serbia, its scope, possibilities, as well as the effects of the previous implementation of the mechanisms of protection of natural resources in our country. This particular research is trying to determine the capacity in the field of protection of rare natural resources, as well as further necessary steps in improving the environmental protection system. This research paper represents an attempt to raise awareness of the protection and conservation of natural resources, the application of appropriate national and international instruments and mechanisms, as well as a better understanding of the concept of environmental protection in Serbia.

\section{World organizations for environmental protection}

WWF - The World's Nature Conservation Fund is an global independent nature conservation foundation that was established in 1961, in Gland, Switzerland. The task of WWF is to stop the degradation of the natural environment and to build a future where people will live in harmony with nature. 
EUROPARC Federation was founded in 1973 under the official title „Federation of Nature Parks and National Parks of Europe" and since then it has grown into a recognized, professional organization of European protected areas. The EUROPARC Federation gathers a wide array of organizations and individuals engaged in vision of policy and park management and protected areas throughout European continent. Modern international diplomacy in the field of environment began in 1972 at the UN Conference on Human Environment in Stockholm.

The World Summit on Sustainable Development (WSSD) was held in Johannesburg, which reaffirmed sustainable development as a central contender on the international agenda and gave a further impetus to protecting the environment and world efforts to combat poverty. Protected areas are very important for several reasons: Providing the necessary benefits from the nature that sustain the human life; Housing of people with traditional cultures and providing irreplaceable knowledge of nature; Helping to preserve the diversity of ecosystems, genetic variability of species and ecological flows necessary for life; Enormous educational, spiritual, scientific, cultural and recreational values; Protected areas have important values as the representatives of the world wilderness (nature), as a cultural and landscape value of significance; Potential models of sustainability of resources that can be applied anywhere in the world (Cvijanović, Simonović, Mihailović, 2011).

\section{History of enviromental protection in Republic of Serbia}

The legal protection of nature in Republic of Serbia began in the 14th century - Dušan's Code (The Law of Tsar Dušan The Mighty) from 1349, where the prohibition of logging was pointed out but also established obligation of planting at the places where the forest was cut down. Despot Stefan Lazarević, in 1412, passed the laws on ores that regulated the ownership, procedure and conditions of use of mineral raw materials. Obed Swamp is the first area that has been placed under protection in the territory of modern Serbia. It was a strict protection by Baron Mollinary in 1874. (Mijatović, Cvijanović, Stajkovac 2011). From natural assets, first protected in Serbia, was the reserve of evergreen trees, tertiary relic, called „Zeleničje“" on the Oštrozub mountain near Crna Trava, protected by a decision of the Ministry of Forestry in 1948 at the proposal of the Natural History Museum from Belgrade. As for the national parks, the Fruška Gora National Park was declared the first national park in Serbia in 1960.

\section{International Strategies for Environmental Protection}

Expansion and intensification of cultivation are among the predominant global changes of this century. Intensification of agriculture by use of high-yielding crop varieties, fertilization, irrigation, and pesticides has contributed substantially to the tremendous increases in food production over the past 50 years. The use of ecologically based management strategies can increase the sustainability of agricultural production while reducing off-site consequences (Marković, Njegovan, Pejanović, 2012). The process of urbanization has brought many benefits to man: technological development, economic 
and commercial progress, however, some of the consequences are: pollution of air and water, accumulation of various waste, the destruction of the ozone layer, global warming of the planet followed by climate change.

The European Landscape Convention of The Council of Europe - Starting from the fact that the diversity and quality, as well as the cultural and natural values of European landscapes represent a common resource, European countries have adopted the European Landscape Convention in 2000, in Florence, Italy. The aim of this convention is to manage, protect and plan all types of European areas, whether rural, degraded, urban or of exceptional beauty, through the introduction of measures at the national level and cooperation at the European level.

International Convention for the Protection of Birds - In 1950, the Convention for the Protection of Birds was adopted and therefore regulated the protection of birds, at the time of nesting and during migration. This Convention is the forerunner of the Ramsar Convention, as it also establishes the obligation to form reserves in aquatic and wetlands in order to ensure the necessary conditions for feeding birds and their nesting.

Ramsar Convention - In Iran, in the city of Ramsar, in 1971, the Convention on Wetlands of International Importance, especially as a birdwatch habitat, was adopted. This Convention refers to the basic ecological functions of the swamp, as a regulator of the water regime and as habitats of specific flora and fauna, in particular the swamp birds.

The Washington Convention - The provisions of this Convention apply to live or dead plants and animals as well as their parts or products made from them. The convention was adopted in 1973 in Washington DC and is an international agreement providing international cooperation in the protection of certain species of wild flora and fauna against excessive exploitation through international commerce.

Convention Concerning the Protection of the World Cultural and Natural Heritage - This Convention was adopted in 1972 and aims to identify, protect and preserve the natural and cultural heritage worldwide, which it considers to be of paramount importance to mankind.

Berne Convention - In 1979, in Bern, a convention was adopted to protect the European wildlife and natural habitats in order to preserve wild fauna and flora and their habitats, especially those habitats and species whose conservation requires the cooperation of several states and the promotion Such cooperation. This convention envisages that each country forms a network of protected natural assets (Stevanović, 2000).

Man and Biosphere (MAB) - Human and natural harmony is the basis of the program "Man and Biosphere", which existed since 1971 within UNESCO. These reserves are crucial for achieving a sustainable balance between conflicting conservation objectives of biodiversity, the preservation of cultural values and the promotion of economic development. The EuroMAB network was established in 1987 and covers 30 countries in Europe and North America. 
Bonn Convention - In Bonn, on June 23, 1979, the Convention on the Conservation of Migratory Species of Wild Animals was adopted. It constitutes an international agreement created by care for those species that migrate outside national borders, that is, accepting that states must be protectors of migratory animal species living within the limits of their jurisdiction.

Natura 2000 - Areas of Natura 2000 are ecological areas in which they want to preserve and achieve favorable conditions for the lives of birds and other animal species, their habitat types and habitat preserved in the interests of the European community. The Natura 2000 network consists of two types of areas: Areas under special protection and Special areas of conservation. Biological diversity at the European level is processed in biogeographical regions.

Parks for Life: An Action Plan for the Protected Areas of Europe - One of the most important „International Union for Conservation of Nature“ (IUCN) projects in Europe since 1994 is the implementation of the action plan for protected areas called „Parks for Life", which has been prepared and implemented in cooperation with the EUROPARC Federation (Nešković, 2012). The basis of the plan consists of about thirty priority projects, of which the Institute for Nature Conservation of Serbia has allocated five and has chosen to implement them, as the most acceptable for our protected areas, namely.

European Centre for Nature Conservation (ECNC) - The pan-European 2020 Strategy for Biodiversity and its Action plan, which established the Pan-European ecological network, was supported in 1995 by the european ministers for environment protection.

European Green Belt Initiative - In 2004, together with its partners, the International Union for Conservation of Nature launched the Green Belt of Europe initiative in order to create an ecological network from Barents to the Black Sea. The aim of the initiative is to encourage cross-border nature conservation and sustainable development.

The Seville Strategy on Biosphere reserves - UNESCO organized an International Conference of Experts in Seville in Spain in March 1995. The strategy developed there, known as the "Seville Strategy", recommends taking the necessary steps for the future development of the Biosphere reserve in the 21 st century.

\section{State of protection and conservation of national resources in Serbia}

In proportion to the size and direction of the provision of the territory, our country is characterized by great genetic, species and ecosystem diversity. It is therefore classified as one of the most important biodiversity regions in Europe. $40 \%$ of the plant species of the entire European flora grow in the territory of Serbia, while the representation of birds and mammals is about $70 \%$. On the basis of international criteria, the territory of Serbia, together with territory of Bulgaria, is classified into one of six European and one hundred and sixty world centers of biodiversity. However, due to industrial development and population growth, 50 plant species have irretrievably disappeared, and around 120 have been severely endangered, and agricultural development in Vojvodina has changed the 
vegetation. The development of agriculture, urbanism, tourism, as well as illicit trade in plant and animal species have led to disruption of the biodiversity in Serbia. Agriculture's main challenge for the coming decades will be to produce sufficient food and fiber for a growing global population at an acceptable environmental cost.

Serbia is distinguished by its rich and varied natural heritage, which is reflected in a wide spectrum of geological, geomorphological, palaeological, climatic, hydrological and biological diversity. The total area of protected natural resources in Serbia is around 516,350 ha, or $6.59 \%$ of the territory. In addition to five national parks, the remaining protected natural resources in Serbia include: 98 nature reserves, 16 landscapes of exceptional features, 296 nature monuments and 24 nature parks. Under the protection of the state there are a total of 215 plant and 426 animal species as natural rarities. Apart from the national parks that have been placed under the protection of the state as a natural good of great importance: Kopaonik, Tara, Đerdap, Fruška Gora and Šarplanina (Mijatović, Cvijanović, Stajkovac 2011).

The impact of the changed environment on living beings is reflected in the change of biochemical processes, metabolism, growth and development, physiology, which can endanger the health and life of people, as well as other groups of organisms As an element of nature that has a pronounced geological, biological, ecosystem diversity, protected natural assets are very important, especially in the urban environment.

Within the "MAB-Man and Biosfere" project, Serbian government proposed NP "Tara", Upper Morava and Drina Biosphere Reserve. The areas of Labudovo okno and Upper Danube would be protected under the Ramsar Convention (The Convention on Wetlands of International Importance, as a regulator of the water regime and habitats of characteristic flora and fauna. The Institute has also identified 35 bird areas that meet the criteria of the IBA project (evaluation of areas of importance for birds), sponsored by Bird Life International. In our country, 13 areas of international significance for butterflies have been identified. Pančićeva omorika, which can be found exclusively on Mountain Tara, is an endemic and relict specie, a descendant of species that in Europe, during the tertiary period before the Ice Age. Due to the specific conditions on the Balkan Peninsula, omorika could be considered, as a representative of the extinct vegetation. Regarding the reservation, 71 nature reserves, totaling 84,000 ha, have been declared in Serbia so far. On the surface of more than 100 hectares, there are special nature reserves: Ludoš Lake, Upper Danube, Karađorđevo, Stari Begej-Carska Swamp, Kovilj-Petrovaradin Marches, Zasavica, Deliblato Sands, Obed Swamp, Mustafa-Feljana, the Gorge of the river Resava, the Gorge of the river Uvac etc. Zasavica is protected as a special nature reserve. So far, over 600 plant species have been recorded in this area.

In the first degree of protection, which makes the smallest area within the national park, all activities except scientific and research activities are strictly forbidden. In the protective zone of the National Park Tara, based on the latest research of the Institute, natural values were valorized, resulting in the proclamation of Šargan-Mokra Gora for a landscape of exceptional features and proposals to protect the Zaovine area with the Gorge of the river Rzav. 
As the unique professional institution for nature protection in our country, the Institute has proposed ten areas for biosphere reserves. The Serbian Ministry of Enviromental Protection operates the Commission for Cooperation with UNESCO, within the framework of the MAB (Man nad Biosfere) committee, to which the Institute proposes a preliminary list. Within the framework of the MAB-UNESCO project „Man and Biosphere", in 2001, Nature Park Golija was registered in the list of biosphere reserves. In addition to Nature Park Golija, the other nine nominated areas are: Đerdap, Tara and Šar Mountains, Special Nature Reserves Upper Danube, Obed Swamp and Deliblato Sands, Stara Planina, Kučaj Mountains and Prokletije. In Serbia, there are 35 areas important for birds that meet the IBA criteria (BirdLife International). Four protected natural assets in Serbia were registered at the so-called Ramsar list (Mijatović, Cvijanović, Stajkovac, 2011).

\section{Protected national resources in Republic of Serbia}

The territory of Serbia, as well as the entire Balkan Peninsula, is distinguished by the extraordinary natural resources and diversity of the living world that places this area in one of the most important centers of biodiversity in Europe. Serbia occupies only $2.1 \%$ of the European continent and on its territory lives: $74 \%$ of birds of Europe, $67 \%$ of European mammals, $51 \%$ of European fish fauna, $49 \%$ of fauna of reptiles and amphibians of Europe and 9\% of Europe's vascular flora.

So far, about 44,200 plants, animals and mushrooms have been officially registered in Serbia. Much of the biodiversity in Serbia is part of the protected natural areas, especially the National Parks. National parks provide one of the highest, integral forms of nature protection based on an ecological concept that plant and animal species, their populations, biocenoses and ecosystems can be protected most effectively through the complete protection of their natural habitats (so-called in-situ conservation of biodiversity).

\section{National Park, Đerdap"}

National Park „Đerdap” was founded in 1974. It is located in northeast Serbia, on the border with Romania. Đerdap is the largest National Park, it covers an area of 64,000 ha. The park is located on the right bank of the Danube and extends from Golubac to Karataš (near Kladovo) i about 100 kilometers long. It covers a narrow forested mountain and mountain belt along the Danube, which rises from 50 to 800 meters above sea level. The main natural phenomenon of the area is the Đerdap Gorge of the Danube, the longest and largest peak of the breakwater in Europe, about $150 \mathrm{~km}$ long. The narrowest part of the gorge, where the Danube is the deepest, known as the „Great Kazan”, is at the same time the most attractive part of the whole area. In the Đerdap area there are over 50 different types of forest and shrub communities today, of which 35 are a relic. In Đerdap there are a total of 150 species of birds, 57 species of fish, 49 species of mammals, including 6 species of bats, of which 3 species are on the European red list and 17 species of rodents. Within the national park, 8 nature reserves and one area of exceptional qualities were declared (Veliki i Mali Štrbac). 
Because of its border status, the National Park „Đerdap“ is planned to be included with its natural whole in Romania Parcul Natural Portile de Fier in the Network of border areas, and due to its outstanding cultural and historical monuments and preserved autochthonous nature it is proposed to be included in the UNESCO World Heritage List and into the world network of biosphere reserves through the program „Man and Biosphere“6.

The international community brings many documents with the aim of protecting and sustainable development of natural resources such as Đerdap, and on the national plane, accompanying documents are being prepared in accordance with international standards. The experiences of developed countries indicate that effective action is by reasoned pressure on polluters, which results in the fact that they take measures to minimize pollution at the prescribed permissible limits (Mijatović, Cvijanović, Stajkovac 2011).

\section{National Park, ,Šar-planina ${ }^{66}$}

National Park „Šar-planina“ (Šar Mountain) is the ,youngest" national park in Serbia, founded in 1986 and covers part of the northern side of the Šar-planina mountain range (in the southwestern part of Kosovo and Metohija). It covers an area of 39,000 ha. Šarplanina is a typical highland area with 30 peaks over $2500 \mathrm{~m}$ high and even 100 peaks over $2000 \mathrm{~m}$. The highest peak is Bistra at 2,661 m above sea level. In Šarplanina, traces of ice age are present at almost every step with a whole series of glacial cirque and lakes. Šar-planina is one of the most important centers of biodiversity in the Balkan Peninsula. With about 2000 species of vascular plants, this mountain covers about $56 \%$ of Serbia's flora. The Animal World of the National Park Šar-planina is characterized by exceptional diversity. There are 147 species of butterflies, over 200 registered bird species and 32 different species of mammala. The bearded vulture disappeared from Šar-planina, which until recently was his last refuge in Serbia. The lynx in the National Park enjoys special protection within the „Special Zoological Reserve on Rusenica“.Because of the exceptional natural values and numerous cultural and historical monuments, the National Park Šar-planina is proposed for international protection through UNESCO's World Natural and Cultural Heritage Program and „Man and Biosphere“.

\section{National park, ,Fruška Gora“6}

National park "Fruška Gora" is oldest national park in Republic of Serbia, declared in 1960. It is located in the southeastern part of the Pannonian Basin (between Danube and Sava), occupying an area of over 25,000 ha, which includes the entire forest mountain wreath of Fruška Gora. The highest peak is the Crveni Cot of $539 \mathrm{~m}$.

Although small in space and height (with features of mountain relief), Fruška Gora is distinguished in geological terms by the presence of different types of rocks, as well as the chemical and mineralogical composition.

Fruška Gora is distinguished by the great diversity of the plant world. There are 32 species of fern, aof which 6 species are on the list of strictly protected flora. About 1000 species 
of vascular plants grow in the National Park area, and the total number of 1450 taxa in the whole area of Fruška Gora represents more than 1/3 of the total flora of Serbia. 73 species are on the list of strictly protected. The basic type of vegetation on Fruška Gora is the deciduous forest. Fruška Gora is home to about 500 medicinal and potentially medicinal plant species. In the area of the park there are as many as 16 Orthodox monasteries dating from the late 15 th and early 16 th centuries, up to 18 th century.

\section{National Park, Tara ${ }^{66}$}

National park ,Tara“" was founded in 1981. It is located in the west part of Serbia. It covers an area of 19,200 hectares. Tara mountain represents a surface of 1000 to 1200 $\mathrm{m}$ high, with its rising peaks from 1400 to $1600 \mathrm{~m}$ above sea level, sprinkled with river valleys. In addition to the canyon valley of the Drina with powerful limestone sections high and over $1000 \mathrm{~m}$, therea are the canyons of rivers Raca, Brusnica, Derventa and White Rzav.

There are 171 species of moss in the Tara area, 30 species of ferns, 7 species of gymnosperms, 950 marshmallows, altogether over 1100 species, representing 1/3 of the total flora of Serbia. Tara was proclaimed National Park primarily because it is one of the most forested mountains in Europe, with some forest complexes being one of the most well-preserved and most productive in Europe. Forest ecosystems occupy about $70 \%$ of its total territory. Pančić's omorika develops in very different habitats, on rocks or on crevices, mixing with different types of hardwoods and softwoods. At the same time, other communities of trees, and even individual, are protected by law as natural rarities. Of the pure coniferous forests of the National Park Tara, there are especially important forests of black pine, white pine forest, and various mixed forests.

There are 280 medicinal and aromatic plants on Tara, and for this reason, measures have been taken to plant this species on the Tara mountain, which has proved to be very successful, thus protecting natural populations. The animal world of Tara National Park is very diverse, with 115 species of butterflies, 27 species of fish, 12 species of amphibians, 12 species of reptiles, about 170 bird species and 51 species of mammals. Especially significant and legally protected are brown bear, chives and roe deer. Bearing in mind all the natural values and specificities of this area, an initiative has been launched to place the National Park Tara in the list of World Natural and Cultural Heritage, to be included in the network of biosphere reserves (UNESCO) and in the network of border areas under the name „Drina“"

\section{National Park ,Kopaonik“6}

National Park Kopaonik was protected in 1981 and covers an area of roughly 11,809 ha. It extends to the highest and most preserved parts of the mountain Kopaonik, which rises in the central part of southern Serbia. The base of the park is a highland, relatively rugged area of medium hight above sea-level of about $1700 \mathrm{~m}$. The lowest point is about 640 m, while the highest point represents Pančićev vrh (Pančić's Peak) at a height of 2017 
m. Kopaonik is a mountain of extremely complex geological structure. There are 219 mushroom species in the Kopaonik area, 120 species of lichens, 350 species of algae, about 150 species of moss, and even 1600 species of vascular plants. The presence of 825 species and subspecies of vascular plants has been recorded from this exceptionally high diversity of flora for the highland area above $1600 \mathrm{~m}$ above sea level. Today in the National Park Kopaonik there are 91 endemic and 82 subendemic species, which suggests that Kopaonik is one of the most important centers of endemism in Serbia.

In the Kopaonik area there are 14 species of amphibians, 13 species of reptiles, 148 bird species and about 60 species of mammals. However, only the highest parts of the mountain, perhaps because of the crude nature, have been preserved until recently. Today, through these forests, there are many kilometers of ski slopes and lifts that make the threat to the living world maximized. Many species have disappeared, a dozen of them are in direct danger, and a hundred very rare plant species can easily become endangered and completely disappear from this area. Kopaonik's problems include illegal construction, wastewater and municipal waste. If all these problems are not solved before long, there is a great chance for Kopaonik to lose its status as a National Park.

\section{National Strategy for Approximation of Environment of the Republic of Serbia}

National Strategy for Approximation of Environment of the Republic of Serbia (2010) was prepared in close cooperation with the Ministry of Environment, Mining and Spatial Planning and the Ministry of Agriculture, Forestry and Water Management, Ministry of Infrastructure, Ministry of Finance, Office for European Integration of the Republic of Serbia and representatives of the Autonomous Province of Vojvodina. Support for the preparation of this Strategy was also provided through technical assistance funded by the European Union through the Instrument for Pre-Accession Assistance (IPA), and implemented by Eptisa Servicios de Ingeniería S.L. from Spain and Project Management Ltd. from Ireland.

Over the past decade, great progress has been made in improving environmental protection in Republic of Serbia, but much remains to be done. For example, while in the EU almost $90 \%$ of wastewater is treated before discharge, and almost $100 \%$ of municipal waste is collected, in Serbia only $10 \%$ of wastewater is treated before discharge, and only $60 \%$ of municipal waste is collected. In addition to this, solid municipal waste collected in large quantities must be disposed of in landfills that do not adequately protect the environment or public health. Less than $15 \%$ of municipal solid waste collected in Serbia is deposited in landfills that meet EU standards, unlike the average in the EU where it is $99 \%$. Likewise, while $40 \%$ of municipal solid waste is recycled in the EU, this rate is only $4 \%$ in Serbia.

The latest enlargement of the European Union shows the complexity involved in creating the conditions for full compliance with the EU environmental regulations - especially in the situation where the current environmental protection in our country is lagging behind in the EU. In order to overcome this challenge, there is a need for sustainable 
progress in three specific areas: the transposition of EU environmental regulations into national regulations, the establishment of administrative capacities for the implementation of environmental regulations, monitoring and implementation of these regulations, and the establishment of the infrastructure necessary for implementation of these regulations. In the current institutional structure of the Government of the Republic of Serbia, successful implementation will require the improvement of the current inter-ministerial channels of cooperation (Nešković, 2012).

\section{Conclusions}

Humanity is confronted with a multitude of existential crises, among which the ecological crisis takes a special place. So far, man has been unable to create an ideal system of civilization and avoid the crisis situations of that system. Ecological awareness represents the necessary basis for further, sustainable development of environmental protection. The strategic approach of Serbia includes all relevant entities of the state, especially economic diplomats who represent and affirm serbian national, primarily economic resources on the international plane (Nešković, 2012).

In the 21 st century, society faces the following global problems: damaging the biosphere and its ecosystems, a huge population - over 6 billion with a doubling projection by 2020, exhaustion and reduced volumes of many sources of mineral and energy raw materials, pollution and degradation of air, water and land, global climate change, destroyed species of plant and animal life and further endangering biodiversity, human health, large amounts of waste in all three aggregate states, and so on. The survival of human communities has been often endangered in the past by natural disasters, epidemics, wars, food scarcity and other influences which, however, have always been spatially limited. Unlike the existential crises of the past, today's crises do not come from natural disasters that are spatially restricted, but from global discrepancies in the conceptual and material purport of the industrial civilization.

So far, man has been unable to create an ideal system of civilization and avoid the crisis situations of that system. For now, there are no integral system studies that would clarify the true dimensions of these problems as well as the real possibilities for their solution. The ideas of a consumer society have one single goal: to produce large quantities of products that are cheaper, regardless of the applied technologies, i.e. the harmful consequences they have on the environment and which lead to more pollution. The survival of many plant and animal species is endangered today, many are found to be fading away, and many have disappeared forever.

Agriculture depends heavily on natural resources for inputs, for example, water, soil and fertilizers and is often at the same time in compettion with other industries. If the amount of natural resources avalaible to agriculture falls either because agriculture uses natural resources insustainably or because other industries do this, agricultural production will fail to be maintained. In addition, agriculture, other industries and households use natural enviroment as sinks for disposal of their wastes. Such disposal 
can reduce the amount or quaity of resouces avalaible for agricultural production and so result in lack of sustainability of agricultural production. In relation to agricultural development, it can support the view that conservation of the natural resource-base of agriculture is not so important because erosion of this base can be compensated for by increased human investment and technological progress. Agronomists must embrace ecology and ecologists need to become more involved in thinking about agricultural systems. Both must be willing to work with economists and other social scientists to appropriately identify services that can be valued.

\section{Conflict of interests}

The authors declare no conflict of interest.

\section{References}

1. Altieri, M., (2004): Linking ecologists and traditional farmers in the search for sustainable agriculture, Frontiers in Ecology and the Enviroment, The Ecological Society of America, Washington DC, USA.

2. Antevski, M., Petrović, P., Vesić, D., (2012): Development perspectives in agriculture and rural areas in Serbia in the EU integration process, Economics of Agriculture, 59 (2), IAE Belgrade, Serbia.

3. Cvijanović, D., Simonović, Z., Mihailović, B., (2011): Focus and objectives of the recent reforms of CAP EU regional policy, Economics of Agriculture, 58 (3), IAE Belgrade, Serbia.

4. Mijatović, N., Cvijanović, D., Stajkovac, J., (2011): Protection and sustainable development of the Danube Region ecosystem, Economics of Agriculture, 59 (SI-1), ISM Vrdnik, Serbia.

5. Lutwak, E., (1990): From Geopolitical to Geo-economics, Logic of Conflict, Grammar of Commerce, The National Interest, No. 20.

6. Marković, K., Njegovan, Z., Pejanović, R., (2012): Former and future reforms of Common Agricultural Policy of the European Union, Economics of Agriculture, 59 (3), IAE Belgrade, Serbia.

7. Nešković, S., (2012): An agricultural production as a significant area of a strategy of economy diplomacy of Serbia, Economics of Agriculture, 59(4), Belgrade, Serbia.

8. Nešković, S., (2007): National interest and environmental protection in the post-modern global environment, Proceedings, SYM-OP-IS, Zlatibor, Faculty of Organizational sciences, Belgrade.

9. Nešković, S., (2007): Concept of national interest and environmental safety, AIR PROTECTION 2007, Chamber of Commerce and Industry of Serbia, Belgrade. 
10. Radojičić, B., (2009): Food safety in relation to EU legislation (EU), Proceedings, No. IV, Security in postmodern ambient, CESNA B, Belgrade.

11. Radojičić, B., (2011): Action Plan on the Status of BSE in the Republic of Serbia and International Trade Exchange, Proceedings, No. VI, Security in postmodern ambient, CESNA B, Belgrade. 